\title{
A Female Scribe in the Twenty Sixth Dynasty
}

\author{
(Iretrau)
}

\author{
Heba Maher Mahmoud Ahmed
}

hebamaher@mans.edu.eg

Lecturer, Faculty of Arts, Mansoura University, Egypt.

\begin{abstract}
:
This research studies Iretrau's title 'sS-sHm.t' which was mentioned several times in her tomb. This is a clear reference of literacy. It is notable that Iretrau and her position as a scribe is one of the most complicated issues, due to the lack of texts written by her as a male scribe, as well as the absence of writing tools in her tomb. However, there are many other reasons for looking at Iretrau as a literate woman who held a scribal position with actual duties according to previous indications.

The fact that Iretrau used the very plain title of scribe suggests that she was not involved in the administration of the institution directly or assigned certain tasks such as holding a position in a specific office or bureau. She depended solely on her professional status as a Scribe

'Sms.t aA.t $n$ dwAt nTr'. This reflects her role as wife of a vizier and mother of a vizier. Undoubtedly, this independence was related to an increase in the power of the God's wife of Amun institution which was also reflected. Iretrau seemed to be a great change maker in the administration system, simply by being a female scribe, because the power structure of ancient Egypt from the king down was dominated by men entirely, whereas women were not allowed to be part of the governmental bodies or to occupy any governmental positions. On the contrary, Iretrau broke these rules by working outdoors, something which was not applicable to non-royal women. Iretrau's status as a Female Scribe and a Chief Attendants was probably similar to the great Stewards of the God's Wife of Amen. Proof of this is the fact that she was buried in an exclusive tomb in Asasif like the great Stewards of the God's Wife of Amen. It is worthy questioning the reason why Iretrau does not appear as a scribe in her tomb the same way the male scribes appear in their tombs. Could it be that the position of the male scribe was not appropriate for her, but at least it is imperative to see the tools of a scribe in her tomb, while countless scenes show male Scribe at work!
\end{abstract}

Key words: Iretrau, Naaes, Female Scribe, Elite, Psamtichus I, Twenty Sixth Dynasty,

Education, female literacy, Gender, TT 390.

\section{Introduction:}


Titles and what they indicate about roles and status in ancient Egypt remain problematic to the modern scholar. Scholars translate the titles, but rarely have detailed understandings of the functions of these titles, especially in the case of women. Probable occupations as indicated by titles are too often dismissed as honorific or purely ceremonial, not entailing any real responsibilities. ${ }^{1}$ There were some occupations, such as the military which were only for men. Both women and men could be cultic singers, although women more often performed this role. ${ }^{2}$

Occupation of a Scribe was one of the most important occupations in ancient Egypt. Those people who had successfully taken up the arduous task of learning to read and write. This was considered an elite class has been instrumental in Egypt, especially when it came to the successful execution of their many famous monumental building projects. Scribes played a central role in the Egyptian administration and were universally held in high regard. ${ }^{3}$

There were occasional female scribes and administrators ${ }^{4}$, but there are few discussions regarding whether a female scribe had responsibilities different from those of a male scribe. ${ }^{5}$ Also there are far fewer indications of women participating in physical activity than there are showing men at work and play. While this may or may not mean that there

${ }^{1} \mathrm{~J} . \mathrm{Li}$, Elite Theban Women of the Eighth-Sixth Centuries BCE in Egypt: Identity, Status and Mortuary Practice (Berkeley, 2010), 26.

${ }^{2}$ U. Matić, 'Gender in Ancient Egypt: Norms, Ambiguities, and Sensualities', NEA 79 No. 3 (2016), 175.

${ }^{3}$ V. A. J. Loon, Law and Order in Ancient Egypt: The Development of Criminal Justice from the Pharaonic New Kingdom until the Roman Dominate (MA. diss., Leiden, 2014), 7.

${ }^{4}$ Matić, NEA 79 No. 3 (2016), 175.

${ }^{5}$ L. Sabbahy, 'Women, Pharaonic Egypt: from EAH', in R. S. Bagnall (ed.), the Encyclopedia of Ancient History (Malden, 2013), 2. 
were fewer activities in which women participated, it does suggest that the men had control over such things as tomb-paintings, writing and so on. ${ }^{6}$

In the Late Periods two women appeared as female scribes; 'Iretrau' is referred to unambiguously as a female scribe in Twenty Sixth Dynasty. ${ }^{7}$ There was another woman called 'Naaes' who bears the office of scribe on her stone stela provenanced to Dra Abu elNaga. Unfortunately the inscription is not clear but nonetheless, the word 'scribe' is legible. ${ }^{8}$

This research is examining the case of 'Iretrau' 'the female scribe in Twenty Sixth Dynasty', plans to study the following:

- Iretrau's Identity.

- Her education; how she learned the basics of the scribal occupation?

- How she achieved this position in Thebes?

- Accepting her as a scribe with real duties.

\section{Iretrau's Identity:}

She has been identified as the mother of 'Nespakashuty D', who was the vizier of 'Psamtichus I', as was his father', according to the texts in her tomb, her parents were the Divine Father 'Ipwer' and 'Tashaiu' ${ }^{10}$ :

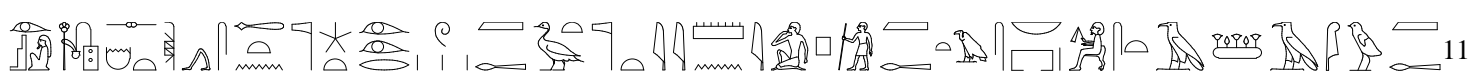

${ }^{6}$ M. T. P. Brian, 'Women Sex Objects in Ancient Egypt', in: the Fourth Annual Convention of the North American Society for Sport History at The University of Oregon, June 16-19 (1976), 5.

${ }^{7}$ H. Brunner, Altägyptische Erziehung, trans. Mostafa abd El baset (Egypt, 2011), 80; S. C. E. Hansen, Das Gottesweib des Amun (København: Ejnar Munksgaard, 1940), 38; G. Robins, Women in Ancient Egypt (London: British Museum Press, 1993), 111, 113; J. Li, Women, Gender and Identity in Third Intermediate Period Egypt (New York: 2017), 37; Li, Elite Theban Women, 36.

${ }^{8} \mathrm{Li}$, Elite Theban Women, 36; Li, Women, Gender and Identity, 37-38.

${ }^{9} \mathrm{Li}$, Elite Theban Women, 123; For the Vizier Nespakashuty, see; E. Pischikova, 'Reliefs from The Tomb of The Vizier Nespakashuty: Reconstruction, Iconography, and Style', MMJ 33 (1998), 57-101.

${ }^{10} \mathrm{PM} \mathrm{I}^{1}, 440$

${ }^{11}$ J. F. Champollion, Monuments de L'Égypte et de La Nubie: Notices Descriptives Conformes aux Manuscrits Autographes Rédigés Sur Les Lieux I (Paris 1929), 511 (A), (B); LD. 3, 271 Nrs a. b, 272 Nr. b. 
Wsir sS sHm.t Sms.t aA.t n dwA.t nTr Irt-ir-w ${ }^{\mathbf{1 2}}$ mAa.t xrw sA.t it-nTr (n) Imn Ip-wr mAa xrw mwt.s nb.t pr Sps.t tAS-iw mAa.t xrw.

[The deceased, Female Scribe, Chief Attendant of Divine Wife 'Iretrau', Justified, Daughter of Divine Father of Amun 'Ipwer' Justified, Her Mother, Mistress of the House, Noblewoman,'Tashaiu', Justified]. ${ }^{13}$

\section{Iretrau as a female Scribe 'sS sHm.t' and her Education:}

Iretrau's title of scribe is mentioned numerous times in her tomb. ${ }^{14}$ It means that Iretrau appeared as a clear evidence for female literacy. ${ }^{15}$ She probably arrived at Thebes in 656 B.C, when Nitocris was installed in her Theban office ${ }^{16}$, she was probably associated with the God's Wife of Amun-Re and held true bureaucratic responsibilities. ${ }^{17}$

But, we must wonder about her education and how she learned the basics of the scribal occupation, especially since it is very rare to find female scribes between male scribes throughout the ancient Egyptian history, but we cannot decide that women in ancient Egypt were illiterate, especially in cases of queens which had political roles, God's Wives, and female priests, in addition to the deity of writing in ancient Egypt was a female 'Seshat', and

${ }^{12} \mathrm{PN}$ I, 42.

${ }^{13} \mathrm{PM} \mathrm{I}^{1}, 440$ identifies her parents as the Divine Father Ipwer and Tashaiu, citing Lepsius' description in the LD. However, there seems to be some confusion. In the published sketch in the LD. III (289), Iretrau seems to be the daughter of the God's Father (Divine Father) Iy (possibly read Ipwer) who was the son of the God's Father, Djedhor. Djedhor's wife was 'the Lady of the House and Noblewoman, Iretrau.' There is room for two possible translations. Then 'Jean Li' suggested that the tomb owner would be identified as the daughter of man $x$ and woman $x$, in which case, Iretrau would be the daughter of Iretrau. Since PM I ${ }^{1}, 440$ identifies Iretrau's mother as Tashaiu, the other Iretrau may refer to the wife of Djedhor. Thus Iretrau, the owner of TT 390, was named after her grandmother. Since this appears to be fragment of inscription from TT390, there is no way of determining which of the interpretations is correct. Finally, 'Jean Li' inclined to follow Porter and Moss; Li, Elite Theban Women, 123 no. 116.

${ }^{14}$ Brunner, Altägyptische Erziehung, 80-81; Hansen, Das Gottesweib des Amun, 38; Li, Women, Gender and Identity, 37. 2012), 3 .

${ }^{15}$ K. Zinn, 'Literacy, Pharaonic Egypt', in R. Bagnall (ed.), Encyclopedia of Ancient World (Oxford,

${ }^{16} \mathrm{http} / / / \mathrm{www}$. southasasif.com/History-of-the-Tomb.html.

Accessed April 25, 2018.

${ }^{17} \mathrm{Li}$, Women, Gender and Identity, 38; Li, Elite Theban Women, 37. 
she held the title of female scribe.The ambitions of the ancient Egyptian elite for their sons ${ }^{18}$ centered round giving them proper scribal training and setting their feet on the bureaucratic ladder, the ideal being that the son should inherit the office of his father.

On the other hand, women were excluded from the official bureaucratic structure, and it was boys who were sent to school and encouraged to devote their efforts to becoming scribes. Since women could not join the bureaucracy. They had no need for the skills of literacy, and therefore no need for formal training in them. ${ }^{19}$

But this does not necessarily mean that women never learned to read and write. ${ }^{20}$ May be they learned in an indirect way; by communication with their parents and brothers who learned in a direct way in schools. ${ }^{21}$ Then those daughters who grew up in literate families could pass on their knowledge to their daughters. ${ }^{22}$

In elite families while women could never hope to hold office, they might have been able to write letters to each other, keep household and business accounts, and read or copy literacy texts. ${ }^{23}$

There were many literate women in the ancient Egyptian civilization, although their number was much lower than literate men. ${ }^{24}$ For example, we have letters written by women. The earliest comes from the Old Kingdom (Sixth Dynasty, Cairo Linen CG 25975) and was

\footnotetext{
${ }^{18}$ Brunner, Altägyptische Erziehung, 81-82. We should assume that it was certainly an extensive study to be qualified in everything. In a scene from the Eleventh Dynasty, The director of the dance appears with at least four of her students. There is also an incomplete scene of a man, from his tomb in (Kom el-Hisn in Delta), with ten girls. he was teaching them how to play music with tool in each of his hands while girls hold one tool, then he appeared with female singers. The matter here relates more to religious education than religious performance, because in the many pictures of the temples, no man participated as a conductor of the orchestra. These scenes were about teaching musical education; see, Brunner, Altägyptische Erziehung, 82-85, Pls. 3, 4.

${ }^{19}$ Robins, Women in Ancient Egypt, 111.

${ }^{20}$ Robins, Women in Ancient Egypt, 111.

${ }^{21}$ Brunner, Altägyptische Erziehung, 85.

${ }^{22}$ Robins, Women in Ancient Egypt, 113.

${ }^{23}$ Robins, Women in Ancient Egypt, 113.

${ }^{24}$ Zinn, in Bagnall (ed.), Encyclopedia of Ancient World, 3.
} 
written about a dispute by a wife with regard to her deceased husband. ${ }^{25}$ One Twentieth Dynasty letter tells the recipient; 'and you shall see this daughter of Khonsmose and have her write a letter and send it to me.' Perhaps she really had written by her own hand. ${ }^{26}$

So we must assume exceptional cases of women who became qualified to be scribes, and if we apply this via through Iretrau it means she learned, and became a literate woman by communication with some member of her family especially that she was from an elite family (A wife and a mother of viziers), which qualified her to be a female scribe in institute of god's wife.

\section{The Complicated Matter of Iretrau's Title as a Scribe:}

It is notable that discussion of Iretrau and her position as a scribe is one of the most complicated issues, especially in the absence of texts written by her like most of male scribes. However there is abundant evidence, both written and pictorial, for women in ancient Egypt. We can glimpse the lives of royal, noble, as well as peasant women. However, there are limitations on how clearly we can comprehend their actual status and role in ancient Egyptian society, especially since most of the pictorial evidence we have is from tombs which only royalty or nobility could afford to build. The reliefs and statuary in them show a perfect world meant for the eternal after life, not as a truly realistic depiction of their everyday life or their professional life. ${ }^{27}$

${ }^{25}$ Zinn, in Bagnall (ed.), Encyclopedia of Ancient World, 3; B. M. Bryan, 'Evidence for Female Literacy from Theban Tombs of the New Kingdom', BES 6 (1984), 17-32.

${ }^{26}$ Robins, Women in Ancient Egypt, 113. We cannot say if these women were really literate, and unfortunately there is no firm evidence one way or another. There is no document that we know for sure was penned by a woman or was meant to be read directly by woman. With letters sent to and from women we must always reckon with the possibility that they were written by a male scribe or read out by one to the recipient. In addition, the apparent exclusion of women from scribal activities in the Old Kingdom is also attested by the absence of female 'lector priests'; Robins, Women in Ancient Egypt, 111; H. G. Fischer, Egyptian Woman of The Old Kingdom and of the Heracleopolitan Period (New York: The Metropolitan Museum of Art, 2000), 27; Zinn, in Bagnall (ed.), Encyclopedia of Ancient World, 3.

${ }^{27}$ Sabbahy, in Bagnall (ed.), the Encyclopedia of Ancient History, 1. 
Iretrau is not depicted or shown seated on the ground with crossed legs or one knee standing up, holding a partly unrolled papyrus. ${ }^{28}$ But maybe this was not suitable for women, so Iretrau was not represented in this form.

The group of literate women in ancient Egypt which Iretrau was one of them do not seem to have developed any surviving literary genres unique to themselves, such as a female is equivalent to the male wisdom texts which would have given advice to young women. ${ }^{29}$

The exact duties of Iretrau remain unclear in the God's Wife of Amen institution, although other scribes, men as far as the evidence indicates, are known in the same institution as Scribes for the Domain of the Divine Adoratrice. ${ }^{30}$ In addition to other titles include: Scribe and Chamberlain, Scribe and Overseer of Chamberlains, Scribe of Documents for the domain, Temple Scribe and Seal Bearer. ${ }^{31}$

Since Iretrau used the very plain title of scribe, perhaps it does indeed suggest that she was not directly involved in the administration of the institution or assigned a specific office or bureau, ${ }^{32}$ There is no reason to assume that Iretrau identified herself as a scribe on her tomb. 'Graefe' ${ }^{33}$ emphasized that by his suggestion: 'however, that the entire administration of the god's wife of Amun institution was in the hands of men, overseen by the Great Steward of the God's Wife of Amun, there is no reason to assume, however, that the 'sS.w sHm.t' would have only acted in a private, secretarial nature for the God's Wives of Amun. ${ }^{34}$

\section{Accepting her as a Scribe with Real Duties:}

\footnotetext{
${ }^{28}$ Zinn, in Bagnall (ed.), Encyclopedia of Ancient World, 4.

${ }^{29}$ Robins, Women in Ancient Egypt, 113.

${ }^{30} \mathrm{Li}$, Women, Gender and Identity, 39; Li, Elite Theban Women, 37 no. 32.

${ }^{31} \mathrm{Li}$, Women, Gender and Identity, 39; Li, Elite Theban Women, 37 no. 32.

${ }^{32} \mathrm{Li}$, Women, Gender and Identity, 39; Li, Elite Theban Women, 37 no. 32.

${ }^{33} \mathrm{E}$. Graefe, Untersuchungen zur Verwaltung und Geschichte der Insitution der Gottesgemahlin des Amun vom Beginn des Neuen Reiches bis zur Spätzeit (Wiesbaden: Harrassowitz, 1981), 117-118.

${ }^{34} \mathrm{Li}$, Women, Gender and Identity, 38-39; Li, Elite Theban Women, 37.
} 
We have many reasons for accepting Iretrau as a literate woman who held a scribal occupation with actual duties according to previous indications such as:

- The word 'seshet', the feminine form of the male title 'sesh' 'scribe' was found occasionally in the Middle Kingdom. However, this form is taken by some scholars to be merely a shortened form of a female title which has been understood to mean 'painter of her mouth' or 'cosmetician'. This interpretation would seem to be strengthened by the fact that the title is listed in association with the title of hair dresser. ${ }^{35}$

- Archaeologically, there are examples of female scribes known from stelae and scarabs of the Middle Kingdom. ${ }^{36}$ Apparently the right to use a title and a name on a scarab seal was 'confined to a privileged few by virtue of their office', which suggests that, at least in the Middle Kingdom, the title of female scribe indicated actual duties rather than an honourific status. ${ }^{37}$

- Although, almost all bureaucrats were men in the New Kingdom, there were occasional examples of female scribes, administrators, and some women who helped their husbands. ${ }^{38}$ During the reign of Hatshepsut, women became increasingly active in the Theban clergy. They may also have held a scribal status indicating an administrative position. ${ }^{39}$

- Furthermore, we have visual proof of female literacy in the New Kingdom since traditional scribal palettes published from five different Theban tombs were depicted

${ }^{35}$ Robins, Women in Ancient Egypt, 111.

${ }^{36} \mathrm{~Wb}$. III, 481; W. A. Ward, Essays on Feminine Titles of the Middle Kingdom and Related Subjects (Beirut: American University of Beirut, 1986), 16-18; Li, Women, Gender and Identity, 38.

${ }^{37} \mathrm{Li}$, Women, Gender and Identity, 38; Li, Elite Theban Women, 37 no. 31.

${ }^{38}$ D. Sweeney, 'Sex and Gender', in E. Frood and W. Wendrich (eds.), UCLA Encyclopedia of Egyptology (Los Angeles, 2011), 3; Robins, Women in Ancient Egypt, 111- 114, 116.

${ }^{39} \mathrm{Li}$, Elite Theban Women, 50. 
under women's chairs or on the side of a double chair such as TT84 (Iamnedjeh also holds a rolled papyrus), TT69 (Menna), TT162 (Kenamun), TT147 (unknown), and TT148 (Amenemope). Some of the women with the scribal kit under their chair also held titles of Songstresses of Amun (Smayt nt Imn), or singers in the Amun-temple. ${ }^{40}$

- Palettes bearing the names of Maketaten and her sister Meritaten, daughters of the pharaoh Akhenaten give the impression of being scribal rather than painting palettes, due to the use of only red and black ink as well as writing pens. They might therefore indicate female literacy at least among princesses ${ }^{41}$

- Women appear to have taken on significant administrative responsibilities in Thebes by the end of the New Kingdom, as the Late Ramesside Letters, feature a number of women who held responsibilities regarding paying and provisioning the workers of the Theban necropolis. ${ }^{42}$

This possibility of the existence of female scribes from the New Kingdom may offer a parallel to the appearance of female scribes during the Eighth-Sixth centuries BCE At the same time, throughout the course of the New Kingdom and into the Third Intermediate

${ }^{40}$ Zinn, in Bagnall (ed.), Encyclopedia of Ancient World, 3; Li, Elite Theban Women, 50, no. 50.

${ }^{41}$ Brunner, Altägyptische Erziehung, 81; Zinn, in Bagnall (ed.), Encyclopedia of Ancient World, 3; Tools found in Tutankhamun's tomb. Unfortunately this is not a clear evidence that the princesses were good at writing, It is true that the tools are used and certainly owned by them, but the usual writing tools include only the black and red ink the necessary for writing while the palette included six colors which means that it is closer to drawing than writing; see, Brunner, Altägyptische Erziehung, 81.

${ }^{42}$ E. F. Wente, Late Ramesside Letters, SAOC 33 (Chicago: University of Chicago Press, 1967), 16-17; Li, Women, Gender and Identity, 38; Li, Elite Theban Women, 37 no. 29. There is some evidence for the learning of foreign languages in New Kingdom schools, a fact that historically corresponds to the era of Egyptian imperialism and the extension of Egyptian foreign relations. This evidence, which includes, for example, lists of foreign words or names, is far from conclusive, since it shows more an acquaintance with foreign vocabulary, possibly used in Egyptian texts, rather than mastery over a foreign language. Nevertheless, the occasional use of foreign languages in Egyptian administration (as was the case, for example, at el-Amarna and the famous diplomatic correspondence in Akkadian), was surely a result of some training in foreign languages that could have taken place either in the Egyptian capital or in foreign schools. In addition to these subjects, sports, music, and other arts could have also featured in Egyptian education. The evidence for the treatment of such subjects is, however, scarce; N. Lazaridis, 'Education and Apprenticeship', in E. Frood and W. Wendrich (eds.), UCLA Encyclopedia of Egyptology (Los Angeles, 2010), 6. 
Period there was an increased desire for women to participate in forms of status expressions. ${ }^{43}$ It is therefore clear that ancient Egyptian women were fully capable of functioning as scribes and we may accept that Iretrau was a Female Scribe with actual duties.

\section{Iretrau's Prerogative as a Female Scribe:}

The scribes were always represented as having belonged to a privileged class, a form of intellectual elite. That they were highly esteemed can be found in the texts of ancient papyri and is generally reported in modern books on life in Ancient Egypt. ${ }^{44}$ Iretrau was a unique woman because she belonged to those elite.

Iretrau seemed to be a great change in the administration systemic, simply by being a female scribe, because as we know the power structure of ancient Egypt from the king down, was all males. ${ }^{45}$ While women could not participate in the government bureaucracy or in temple administration to an appreciable extent ${ }^{46}$, Iretrau also broke women's systemic rule by working outdoors a reversal of we know about non-royal women. For example, one of the most common female titles is 'nbt pr' 'Mistress of the House' that women remained at home in charge of the running of household affairs, as we see in documents and tomb scenes where women are shown engaged only in household duties of child rearing and food preparation, as opposed to men, who were engaged in activities outside the household. ${ }^{47}$

Finally, we can imagine that Iretrau did not pay taxes depending on the definition of 'Scribe' profession that contains among others, the following statements: 'His profession was

${ }^{43} \mathrm{Li}$, Elite Theban Women, 50.

${ }^{44}$ S. A. Goudsmit, 'An Illiterate Scribe', AJA 78 (1974), 78.

${ }^{45}$ Sabbahy, in Bagnall (ed.), the Encyclopedia of Ancient History, 1.

${ }^{46}$ Fischer, Egyptian Woman of the Old Kingdom, 46.

${ }^{47} \mathrm{C}$. Lee. Goucher and Ch. A. Le Guin (eds.), Ordering the World: Family and Household, the Balance: Themes in Global History (Boston: McGraw-Hill, 1998), 302; Furthermore, Households were not selfsufficient. Women were responsible for supplying household needs through the exchange and sale of garden provisions, cloth, and other goods. It is likely that in managing the household economy, they could also accumulate wealth, see; Goucher and Le Guin (eds.), Ordering the World, 302. 
the foremost of all the professions. To practice it was an honor. The scribe did not pay taxes.

He was an educated man.' 48

\section{The Reflection her position on her Tomb (TT 390):}

The monumental tomb of Iretrau marked one of the first instances where non-royal women had monuments on a scale never before seen in Egyptian history. TT390 ${ }^{49}$ is one of the major Late Period tombs on the west bank of Asasif, ${ }^{50}$ Iretrau belonged to a prominent Thinite family, therefore her family necropolis is located in Abydos. ${ }^{51} \mathrm{By}$ the time of her arrival at Thebes, she had to choose a new place for her tomb. She decided on the Kushite necropolis ${ }^{52}$ in South Asasif on the South side of Qurna ${ }^{53}$, while few women even among the higher-ranking elite had tombs that reflected this level of personal career orientation. So given Iretrau's monumentally sized tomb must be associate with her position as a Scribe and a Chief Attendant ${ }^{54}$ (pl. 1).

Her spacious tomb contains two pillared halls were never finished. The walls and pillars of the halls are almost completely devoid of decoration with the exception of some

${ }^{48}$ Goudsmit, AJA 78 (1974), 78.

${ }^{49}$ This tomb was visited by 'J. G.wilkinson', 'R. Hey' and 'J. Burton' in 1820, then explored and recorded by 'K. R. Lepsius' in 1840, then observed and photographed by 'D. Eigner' in 1970. It was finally rediscovered in 2001 by the South Assasif Conversation Project; E. Pischikova, Early Kushite Tombs of South Asasif, BMSAES 12 (London, 2009), 19 no. 44.

${ }^{50}$ Asasif is a part of the Theban necropolis, situated in front of the valley of Deir el-Bahari, The royal temples of Deir el-Bahari (Mentuhotep Nebheptre, Hatshepsut and Thutmose III) rise above the plain of the Asasif valley; see, Julia Budka, 'The Asasif Revisited: New Results from The Austrian Concessioni; Originalveröffentlichung', ICE 10 (2015), 111-129; F. Kampp-Seyfried, 'Thebes, el-Asasif', in: K. A. Bard (eds.), Encyclopedia of the Archaeology of Ancient Egypt (London, 1999), 802; D. C. Polz, 'Asasif', in D. B. Redford (eds.), The Oxford Encyclopedia of Ancient Egypt I (Oxford, 2001), 140-142.

${ }^{51} \mathrm{PM} \mathrm{I}{ }^{1}, 440$;

www.Southassassif.com.

Accessed April 25, 2018.

${ }^{52}$ This necropolis located in the South Asasif area, south of Qurna on the Theban West Bank, is not well-known, having been practically lost by the beginning of the Twentieth Century, and only recently rediscovered and re-explored. The importance of the necropolis for the history of private tomb decoration is difficult to overestimate, as it contains the tombs of the Mayor of Thebes and Fourth Priest of Amun Karabasken (TT 391), and that of the First $a q$-priest of Amun, Karakhamun (TT 223). These are the earliest known Kushite decorated tombs in the Theban necropolis, built during the reign of Shabaqo to Shebitqo; Pischikova, Early Kushite Tombs, 11- 30.

${ }^{53}$ www.Southassassif.com.

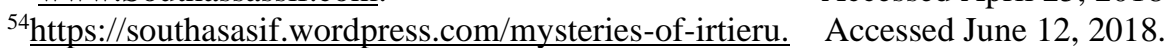


remains of paintings $\mathrm{s}^{55}$, Iretrau's position appeared in every scene; at first in the double scene on the outer lintel of the first pillared hall where the bark of Re in the center, adoreing by Nitocris followed by Iretrau on the left, then Shepenwept II followed by Iretrau adoring Atum on the right.

Standards of the Western Horus, and the Benu-bird are at each end, accompanied by remains of her titles as a Scribe and a Chief Attendant of the God's Wife (pl. 2):

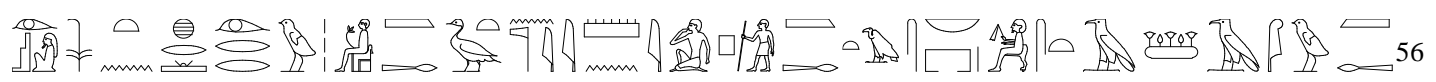

Wsir rx.t nsw Irt-ir-w Sps.t mAa.t xrw sA.t $n$ it-nTr (n) Imn Ip-wr mAa xrw mwt.s nb.t pr Sps.t tA-Siw mAa.t xrw.

[Deseaced, the king's Acquaintance Iretrau, Justified, Daughter of the Divine Father of Amun Ipwer, Justified, Her Mother, Mistress of the House, Noblewoman,'Tashaiu', Justified]

There is an offering-text of the deceased with the name of her father in the ceiling:

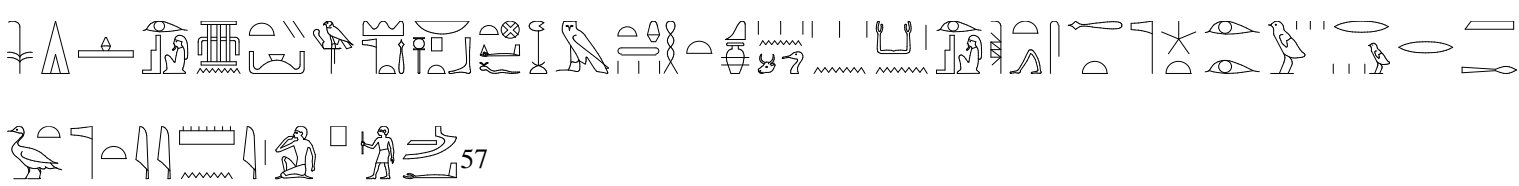

Htp di nsw wsir xnty imntT nTr aA nb AbDw di.f xA m t m Hnqt n KAw Apdw n kA n wsir Sms.t aA.t (n) dwA.t nTr Irt-ir-w mAa,t xrw sA.t it-nTr (n) Imn Ip-wr mAa xrw.

[An offering which the king gives to Osiris, Foremost of the westerners, Great God, lord of Abydos, to give a thousand of bread, a thousand of beer, oxen, and birds for the spirit of the deceased, the Chief Attendant of the God's Wife Iretrau, Daughter of the Divine father of Amun Ipwer, Justified].

${ }^{57} \mathrm{PM} 1{ }^{1}$, 441; Champollion, Monuments de L'Égypte et de La Nubie I, 511(b). 
In addition to remains of her titles on the pillars ${ }^{58}$, she appeared in the outer lintel of the inner room, seated alone before offerings at the left end, with her titles as a Scribe and a Chief Attendant (pl. 3). ${ }^{59}$ Finally, Iretrau appeared with libation-vases before Osiris in the niche containing a false door (pl. 4):

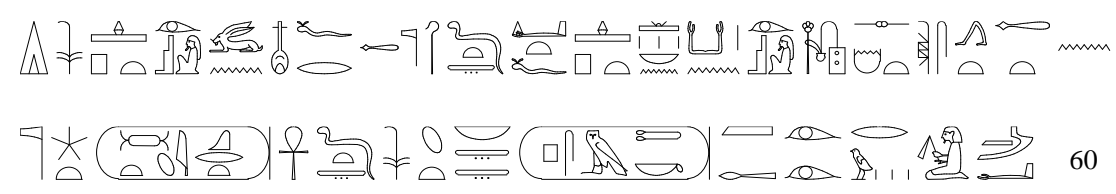

Htp di nsw Wsir wn-nfr nTr aA HQA Dt di.f Htpw nb(.w) n kA n wsir sS.t sHm.t Sms.t aA.t (n)

dwA.T ntr Nit-lqrt anx Dt sA.t nsw nb tAwy PsmTk mAa xrw Irt-ir-w mAa.t xrw.

[An offering which the king gives to Osiris wennfer 'Onnofris', the Great God, Lord of Eternity, to give all offerings for the spirit of the deceased, the Female Scribe, a Chief Attendant of Divine wife Nitocris, Daughter of the Lord of the Two lands, Psmatik, Justified, Irtrau, Justified].

Certainly, these scenes with texts reflect the high position of her as a Female Scribe and a Chief Attendant of the God's wife of Amun (Nitocris). It mostly depicts her as young and a beautiful ${ }^{61}(\mathrm{pl} .5)$, which means she was one of the elite women who were only shown young and beautiful in the perfect state they should be in forever. This is the opposite of nonelite women who could be represented in daily life scenes in the tombs, showing the activities of the tomb owner's estates. In these scenes, the women are active and working: weaving, making beer, serving food, baking bread. Their figures are not bound by the same

${ }^{58} \mathrm{PM} \mathrm{1}{ }^{1}$, 441; Champollion, Monuments de L'Égypte et de La Nubie I, 511 [near top right]. ${ }^{59} \mathrm{PM} 1{ }^{1}$, 441; LD.3. 272 [b]; Champollion, Monuments de L'Égypte et de La Nubie I, 510, 511. ${ }^{60} \mathrm{PM} \mathrm{I}^{1}$, 441.LD.3, 271 [b]; Champollion, Monuments de L'Égypte et de La Nubie I, 5II [A, B]. ${ }^{61}$ http://www.southasasif.com/Irtieru. Accessed June 12, 2018. 
conventions as elite women, because what is important is showing the production of food and goods, not the people doing it. ${ }^{62}$

In addition to appearing alone in most of the scenes; which means she was the most important person here not the secondary person as we usually find in the case of non-royal women who shared the tomb of their husbands according to an elite male perspective. Accordingly means Iretrau was anon royal woman who utilized the privilege of royal women who owned single tombs. ${ }^{63}$ Furthermore, Iretrau did not share her status with her husband like most of women, nor did she derive her status from her husband. Iretrau's husband was of higher rank than she was and was buried in his own ancestral cemetery at Abydos, while her son, also a vizier, had his own tomb in the hills overlooking the Asasif plain. ${ }^{64}$ Undoubtedly, Nespakashuty wanted to be buried next to his mother (pl. 6), so he attempted to usurp the tomb of Karakhamun because the tomb of his mother was adjacent to it. ${ }^{65}$

Thus, it can be argued that the monumental tomb of Iretrau marked the culmination of a development of the increasingly overt independence of women. This growth of independence was undoubtedly linked to the growth in power of the God's Wife of Amen institution, also reflected in the high status cemetery of the 'Singers in the Residence of Amun' at Medinet Habu, and perhaps even earlier in the burial groups of Tashebet in TT192, whose husband was also absent, and of Diesenesyt at Deir el-Bahri. ${ }^{66}$

Finally, it is questionable why Iretrau does not appear as a scribe in her tomb like male scribes in their tombs? Could it be that the seat of the male scribe was not appropriate

\footnotetext{
${ }^{62}$ Sabbahy, in Bagnall (ed.), the Encyclopedia of Ancient History, 2

${ }^{63}$ Sabbahy, in Bagnall (ed.), the Encyclopedia of Ancient History, 1.

${ }^{64} \mathrm{Li}$, Elite Theban Women, 126.

${ }^{65}$ Pischikova, Early Kushite Tombs, 12, 19; A. Booth and M. Booth (eds.), Ramesses and Radar: A collaborative Study of a Tomb Complex at South Asasif, Luxor, Egypt, Nerc Geophysical Equipment Faculty,

${ }^{66} \mathrm{Li}$, Elite Theban Women, 126-127.
} Scientific Report (2012), 5 fig. 5. 
for her, but at least it is imperative to see the tools of a scribe in her tomb, while countless scenes show male Scribe at work.

\section{General Commentary:}

- The ladies had prominent positions, and several were important and influential and played a major role, but overall were one step behind the men. Low born men could improve their lot by becoming scribes, as could the women, but it seems that there were far fewer female-scribes than male. Men could become priests, while ladies could become priestesses, but the most important religious figures seem to have been men, and, of course, the High-Priest was the Pharaoh, who was, almost always, a man. ${ }^{67}$

- Whatever the actual meaning of 'seshet', the contrast between its use and that of the masculine form sesh is striking. 'Sesh' is one of the basic male titles of all periods occurring repeatedly on the monuments. Even if we were to accept all the occurrences of 'seshet' as signifying the female equivalent of a male scribe, the number would be pitifully small. ${ }^{68}$

- There are no depictions from any period of working female scribes, nor can we prove that these few 'seshet' were employed in the state bureaucracy. Since they may rather have held a position in a large private or royal household. ${ }^{69}$

- Clearly, the existence of a few women called 'seshet' does not destroy the basic gender distinction in the elite class between men who were scribes and could hold government office, and women who were not in general, and did not hold office. ${ }^{70}$

\footnotetext{
${ }^{67}$ Brian, the Fourth Annual Convention (1976), 3.

${ }^{68}$ Robins, Women in Ancient Egypt, 113.

${ }^{69}$ Robins, Women in Ancient Egypt, 113.
} 
- It seems that the old Egyptian society did not accept women in many jobs, even as ruling queens. Notable examples are the female kings Neferusobek and Hatshsepsut who had to negotiate between their female sex and their kingship, which was socially defined as male. Neferusobek was sometimes represented wearing a royal kilt and a nemes headdress over a dress. Sobekneferu 'circumvented' the problems created by her gender by proclaiming herself a 'female Horus,' to be like the king of ancient Egypt who ruled by virtue of the fact that he was the god Horus, son of Osiris, and the rightful heir to the throne ${ }^{71}(\mathrm{pl} .6)$. Hatshepsut took this one step further when she became king, and for state purposes simply she had herself portrayed as a man. ${ }^{72}$ She is represented with a combination of male and female elements and she adopted the image of a male king. ${ }^{73}$ Hatshepsut is depicted wearing the 'nemes' headdress and a false beard. She is dressed in the royal kilt, traditionally wore only by male rulers. For example her statue in the (Metropolitan Museum, New York), showed her as a male. She has no breasts and her face looks like that of a man although the waist is thinner than the hips, suggesting a woman. ${ }^{74}$

\section{Conclusion:}

Iretrau was a literate and qualified woman, with many titles and occupations 'a Female Scribe and a Chief Attendant of the Divine Adoratrice'.

\footnotetext{
${ }^{70}$ Robins, Women in Ancient Egypt, 113.

${ }^{71}$ Sweeney, in Frood and Wendrich (eds.), UCLA Encyclopedia of Egyptology, 3; Sabbahy, in Bagnall (ed.), the Encyclopedia of Ancient History, 1; A. Olivier, Social status of elite women of the New Kingdom of ancient Egypt: A comparison of artistic features (MA. diss., University of South Africa, 2008) 69, fig. 35, 9596; A. K. Capel and G. E. Markoe, Mistress of the House, Mistress of the Heaven : Women in Ancient Egypt (Cincinnati : Hudson Hills Press, 1996), 30, fig. 7.

${ }^{72}$ Sabbahy, in Bagnall (ed.), the Encyclopedia of Ancient History, 1.

${ }^{73}$ Sweeney, in Frood and Wendrich (eds.), UCLA Encyclopedia of Egyptology, 3; On the other hand, Hatshepsut's kingly titulary capitalized upon her female sex to build identifications with goddesses that would have been impossible for male kings; she is often described with female nouns and pronouns; Sweeney, in Frood and Wendrich (eds.), UCLA Encyclopedia of Egyptology, 3.

${ }^{74}$ Olivier, Social status of elite women, 95, fig. 52.
} 


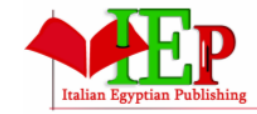

ISSN: 2785-9606
INTERNATIONAL JOURNAL OF ADVANCED STUDIES IN WORLD ARCHAEOLOGY

VOLUME 1, ISSUE 1, 2018, $1-20$.

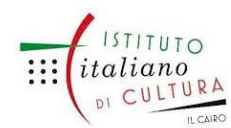

www.egyptfuture.org/oj

Iretrau did not depend on her husband's position or her son, to reach these positions. This may have been due to the power of the position of God's Wife in Twenty Sixth Dynasty. Despite this increased power and independence of women a part from their husbands and fathers, women in general and even queens were still one step behind men in ancient Egypt.

Iretrau's status as a Female Scribe and a Chief Attendants was probably similar to the great Stewards of the God's Wife of Amen, especially since she was buried in an exclusive tomb in Asasif like the great Stewards of the God's Wife of Amen.

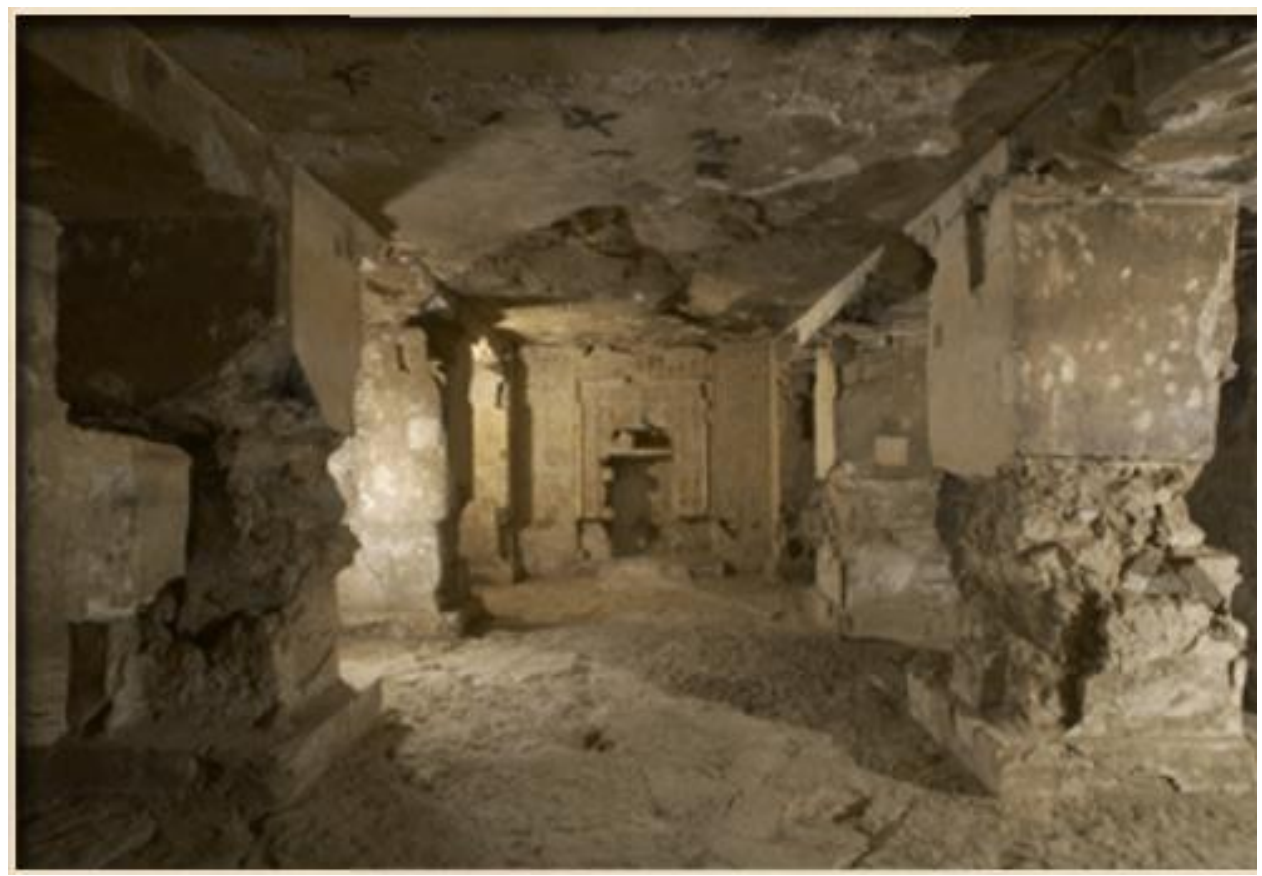

(pl. 1) Iretrau's tomb (TT 390) in south Asasif. http://www.southasasif.com/2nd-Pillared-Hall.html. 


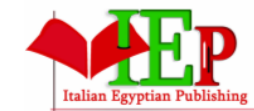

ISSN: 2785-9606
INTERNATIONAL JOURNAL OF ADVANCED STUDIES IN WORLD ARCHAEOLOGY

VOLUME 1, ISSUE 1, 2018, $1-20$.

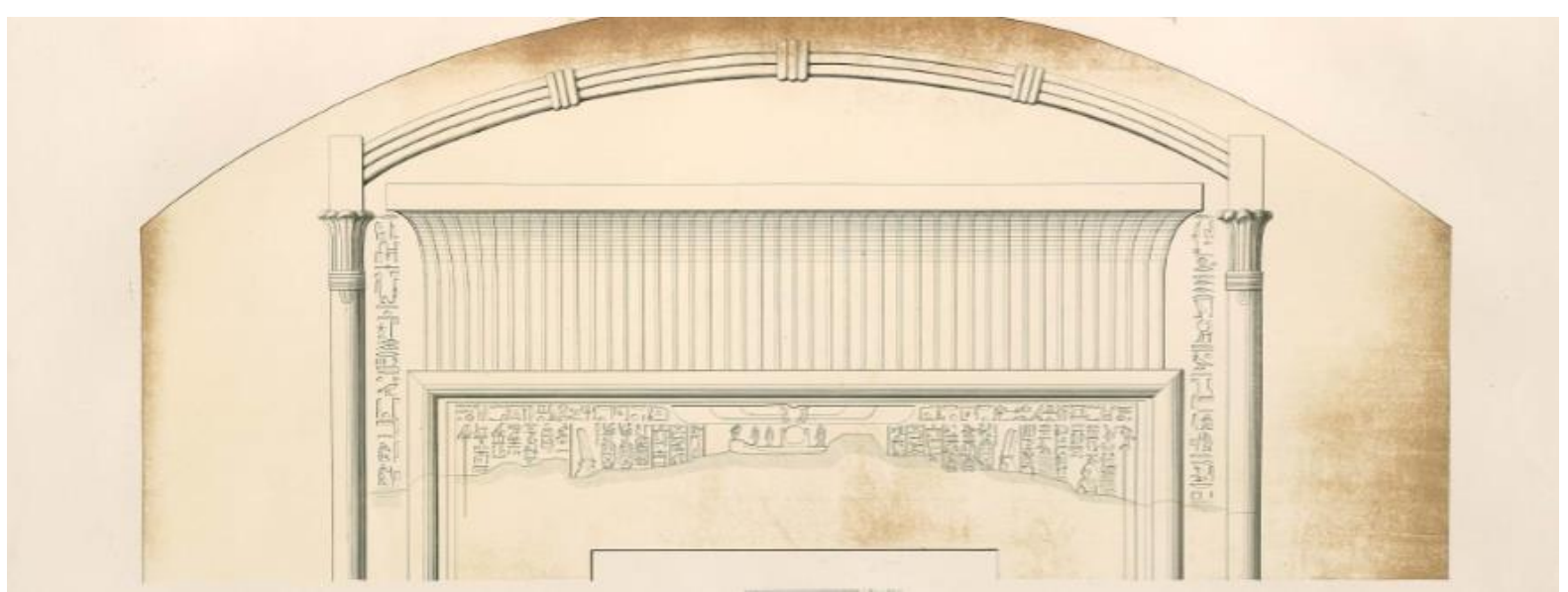

(pl. 2) Double scene in outer lintel of the first hypostyle Hall.

LD. 3, 272 [a].

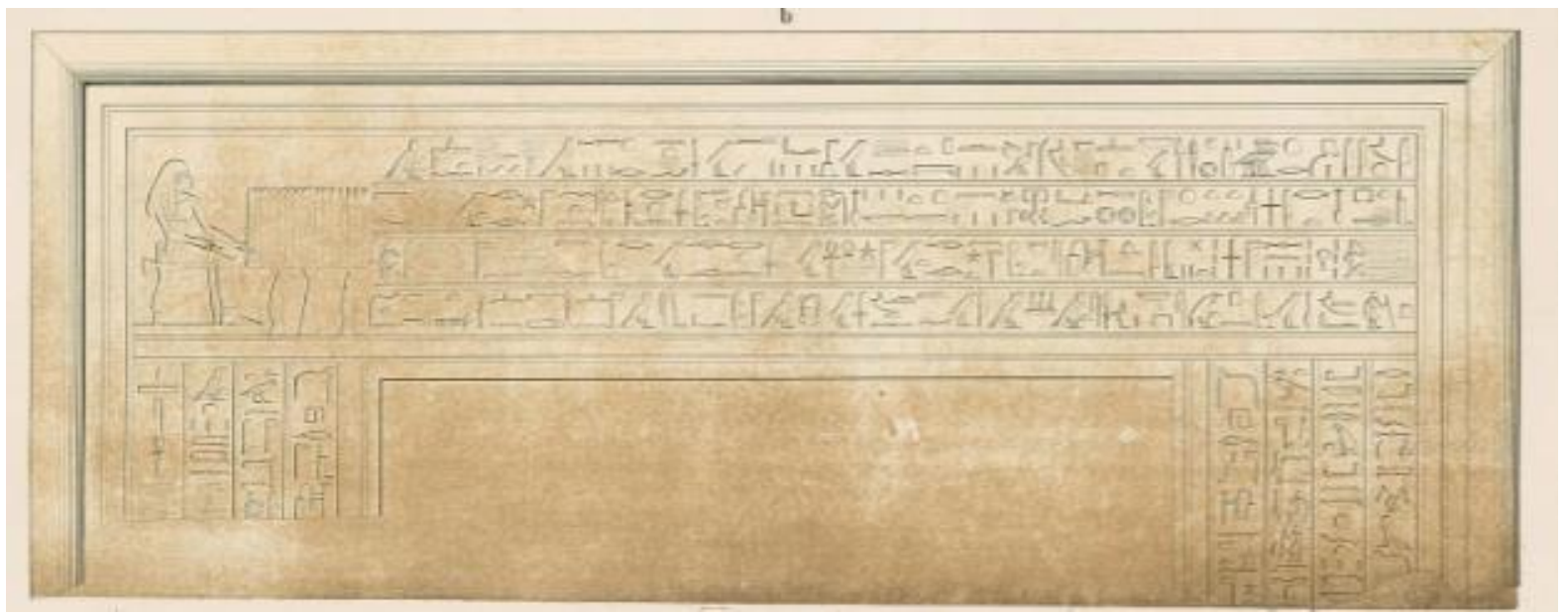

(pl. 3) Iretrau seated before offerings at the left end in the outer lintel of the inner room.

LD. $3.272[\mathrm{~b}]$ 


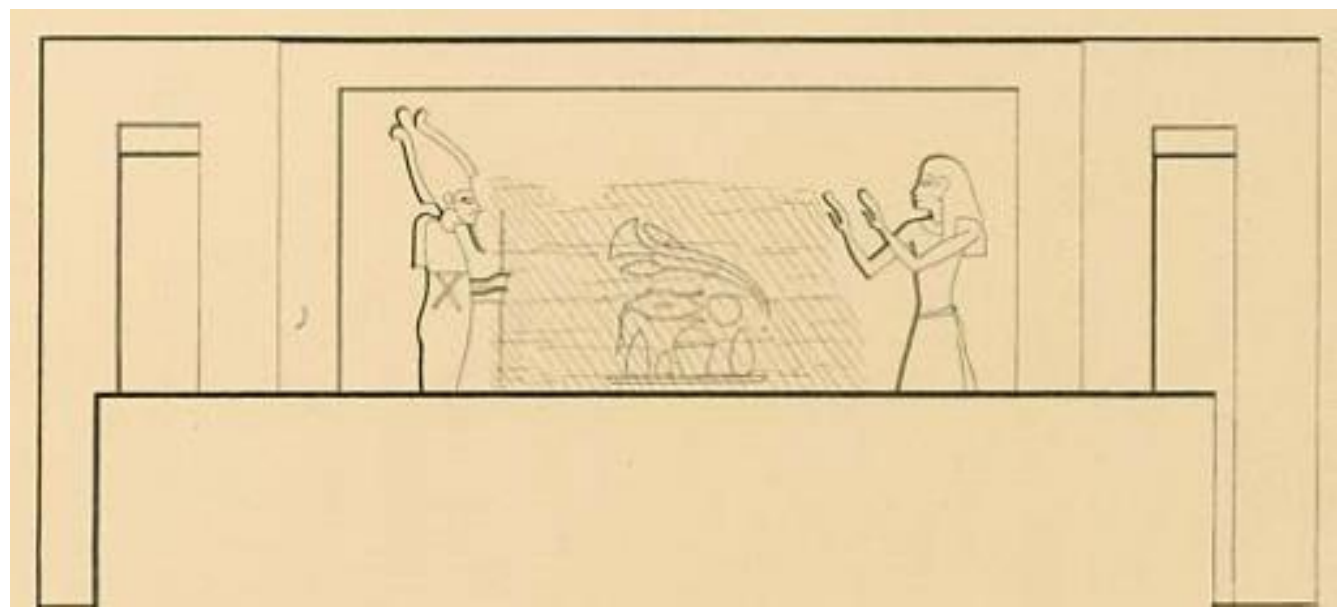

(pl. 4) Iretrau with libation vases before Osiris in niche.

LD. 3. $271[\mathrm{~b}]$.
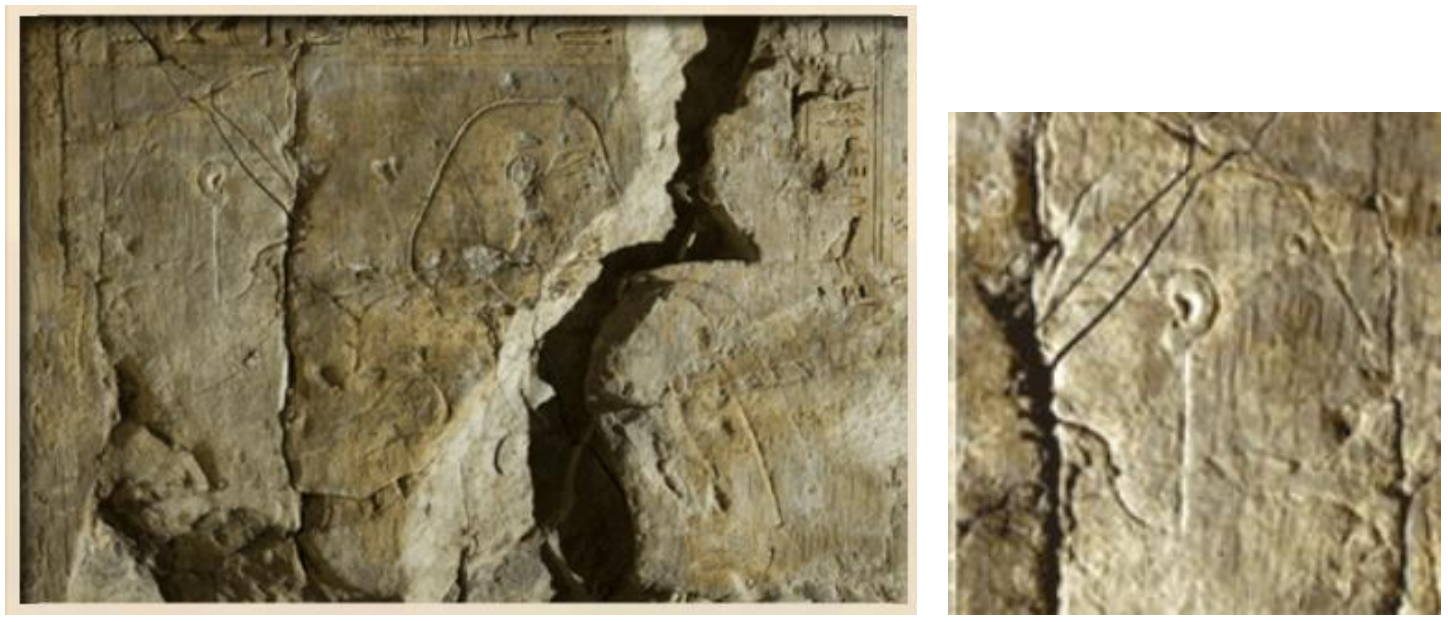

(pl. 5) Iretrau as a young and beautiful woman in her tomb scenes.

http://www.southasasif.com/Irtieru. 


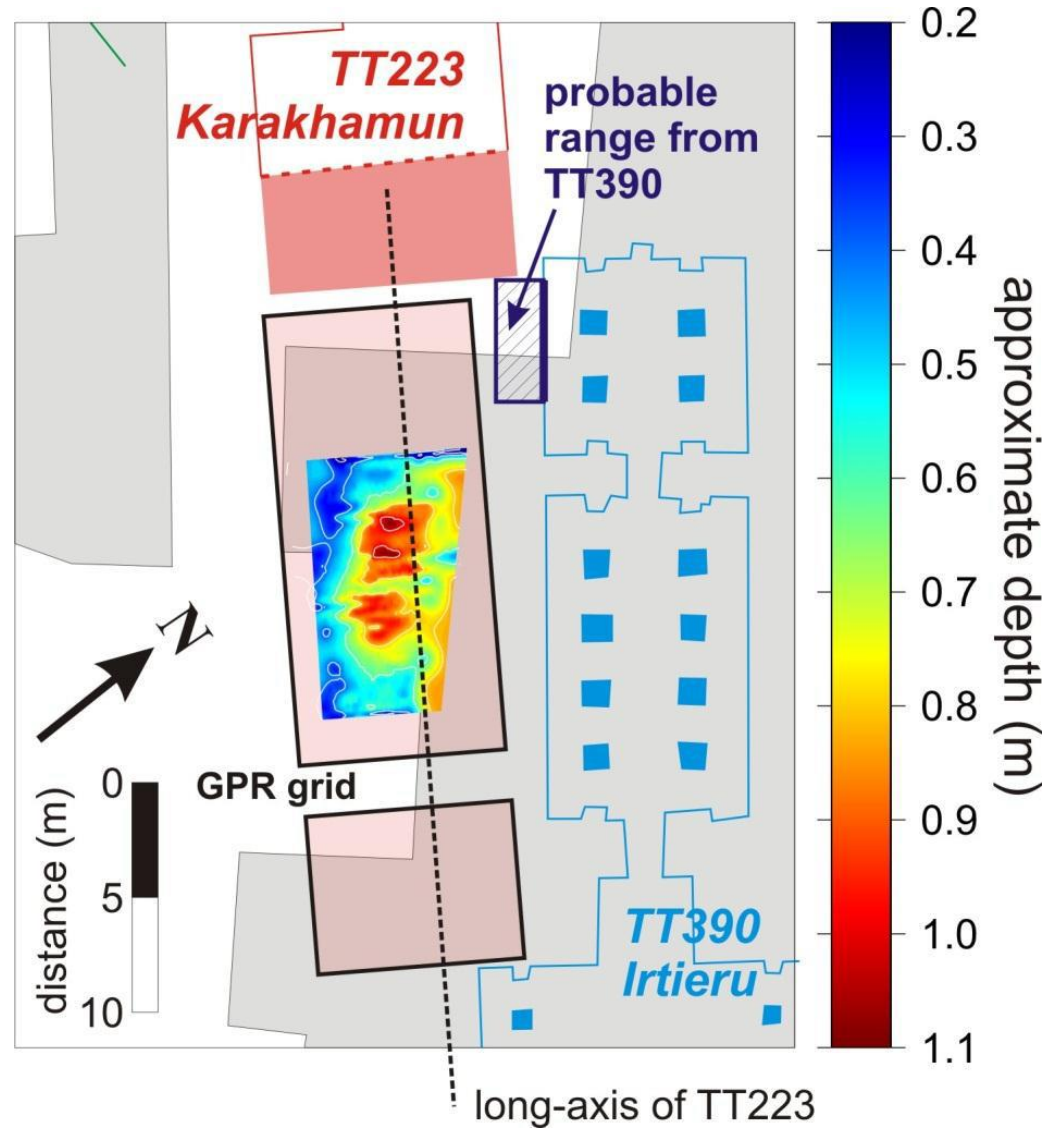

(pl. 6) Iretrau's tomb (TT 390) is adjacent to the tomb of Karakhamun.

Booth and Booth (eds.), Ramesses and Radar 5, fig. 5. 


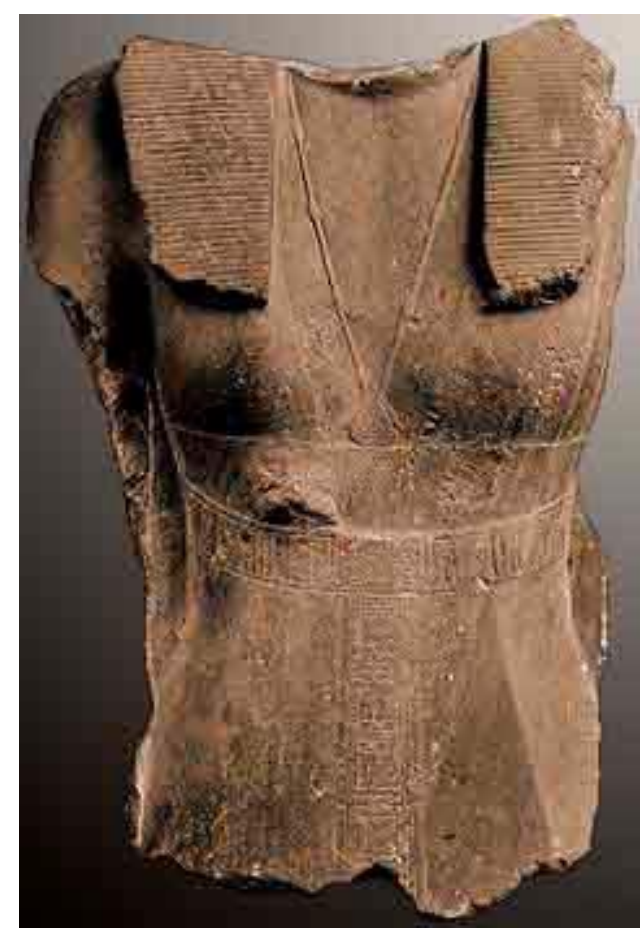

(pl. 7) Torso of Sobeknefru wearing a king's head-dress and kilt, Dynasty Twelve, Louvre Museum, E 27135.

Capel and Markoe, Mistress of the House, 30 fig. 7. 